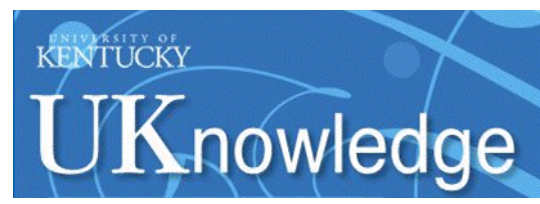

University of Kentucky

UKnowledge

\title{
Constraints on the Emplacement and Uplift History of the Pine Mountain Thrust Sheet, Eastern Kentucky: Evidence from Coal Rank Trends
}

\author{
Kieran D. O'Hara \\ University of Kentucky, kieran.Ohara@uky.edu \\ James C. Hower \\ University of Kentucky, james.hower@uky.edu \\ Susan M. Rimmer \\ University of Kentucky
}

Follow this and additional works at: https://uknowledge.uky.edu/ees_facpub

Part of the Geology Commons

Right click to open a feedback form in a new tab to let us know how this document benefits you.

\section{Repository Citation}

O'Hara, Kieran D.; Hower, James C.; and Rimmer, Susan M., "Constraints on the Emplacement and Uplift History of the Pine Mountain Thrust Sheet, Eastern Kentucky: Evidence from Coal Rank Trends" (1990). Earth and Environmental Sciences Faculty Publications. 9.

https://uknowledge.uky.edu/ees_facpub/9

This Article is brought to you for free and open access by the Earth and Environmental Sciences at UKnowledge. It has been accepted for inclusion in Earth and Environmental Sciences Faculty Publications by an authorized administrator of UKnowledge. For more information, please contact UKnowledge@lsv.uky.edu. 
Constraints on the Emplacement and Uplift History of the Pine Mountain Thrust Sheet, Eastern Kentucky: Evidence from Coal Rank Trends

\author{
Digital Object Identifier (DOI) \\ https://doi.org/10.1086/629373 \\ Notes/Citation Information \\ Published in The Journal of Geology, v. 98, no. 1, p. 43-51. \\ (C) 1990 by The University of Chicago. All rights reserved.
}

The copyright holder has granted the permission for posting the article here. 


\title{
CONSTRAINTS ON THE EMPLACEMENT AND UPLIFT HISTORY OF THE PINE MOUNTAIN THRUST SHEET, EASTERN KENTUCKY: EVIDENCE FROM COAL RANK TRENDS ${ }^{1}$
}

\author{
KIERAN O'HARA, JAMES C. HOWER ${ }^{2}$, AND SUSAN M. RIMMER \\ Department of Geological Sciences, University of Kentucky, Lexington, KY 40506
}

\begin{abstract}
In this paper coal rank trends on both sides of the Pine Mountain thrust in eastern Kentucky are used to place constraints on thrust evolution. Vitrinite reflectance $\left(\% \mathrm{R}_{\max }\right)$ measurements on a single Pennsylvanian coal horizon (Fire Clay coal) in eastern Kentucky increase from $0.5 \%$ in the north to about $1.0 \%$ toward the $\mathrm{SE}$ in front of the Pine Mountain thrust. The same horizon in the hangingwall of the thrust displays lower $R_{\max }$ values $(0.8-0.85 \%)$. The reflectance isograds are subparallel to the thrust within approximately $10 \mathrm{~km}$ of the trace of the fault. We attribute thermal maturation to (1) pre-orogenic maturation by burial to a depth of about $2 \mathrm{~km}$ followed by (2) maturation due to conductive relaxation in the footwall after thrusting. Isotherms would not have been offset unless the thrust velocity was $\gg 10 \mathrm{~km} / \mathrm{Ma}$. Assuming no erosion, the emergent thrust would have been approximately $3 \mathrm{~km}$ thick. In order to explain the relatively low reflectance values observed in the footwall, rapid uplift $(>3 \mathrm{~km} / \mathrm{Ma})$ after thrust emplacement is required. Alternatively, if erosion kept pace with thrusting, the thrust sheet would have been substantially thinner $(<1 \mathrm{~km})$, and thermal equilibrium would be rapidly attained in the footwall. Localized frictional heating may have caused elevated reflectance values observed in sheared coals from outcrop scale faults.
\end{abstract}

\section{INTRODUCTION}

The Pine Mountain thrust in the Valley and Ridge province of the southern Appalachians is a classic example of thin-skinned tectonics (Wentworth 1921; Mitra 1988); this is the locality where it was first demonstrated that subhorizontal detachments commonly stepup stratigraphically in the direction of transport (Rich 1934). More recent studies combining detailed mapping (Miller and Fuller 1954), drillhole and seismic data, as well as balanced cross-section construction techniques (Harris and Milici 1977; Mitra 1988) have provided a detailed three-dimensional kimematic evolution of the Pine Mountain thrust system. Theoretical as well as structural studies (Wiltchko 1979; Wiltchko et al. 1985; Wojtal and Mitra 1986) have provided insight into the mechanism of thrust emplacement. Although valuable information concerning the thermal evolution of overthrusts is often preserved in both high grade (e.g., Oxburgh and Turcotte 1974; Crawford and Mark 1982) and low-grade metamorphic ter-

\footnotetext{
${ }^{1}$ Manuscript received May 25, 1989; accepted August 1989.

${ }^{2}$ University of Kentucky, Center for Applied Energy Research, 3572 Iron Works Pike, Lexington, KY 40511.

[Journal of Geology, 1990, vol. 98, p. 43-51] (C) 1990 by The University of Chicago. All rights reserved.

0022-1376/90/9801-0011\$1.00
}

ranes (England and Bustin 1986; Underwood et al. 1988), this aspect of the evolution of the Pine Mountain thrust has received less attention.

This paper reports on metamorphism of Pennsylvanian coal horizons in eastern Kentucky adjacent to the Pine Mountain thrust. Regional trends of vitrinite reflectance indicate that depth of burial increases toward the thrust belt and that the overthrust itself enhanced maturation of the rocks in the footwall. Elevated reflectance values from sheared coals from the Cumberland pilot tunnel may be due to localized frictional heating. These observations place important constraints on the tectonic and thermal history of the thrust system.

\section{REGIONAL SETTING}

The Appalachian basin, which stretches from Pennsylvania to Alabama, borders the southern Appalachian Valley and Ridge fold and thrust belt on the west; the basin comprises several clastic wedges derived from the east during Paleozoic orogenic events (Rodgers 1983). One of these wedges, the Pennsylvanian-Permian clastic wedge, which thickens to the southeast (e.g., Arkle 1974; Wanless 1975) and consists largely of sandstone, siltstone and shale, was deposited in a foreland basin that developed as a consequence of thrusting during the late Paleozoic Alleghanian orogeny (Tankard 1986). In general, the thermal maturation of these sedi- 


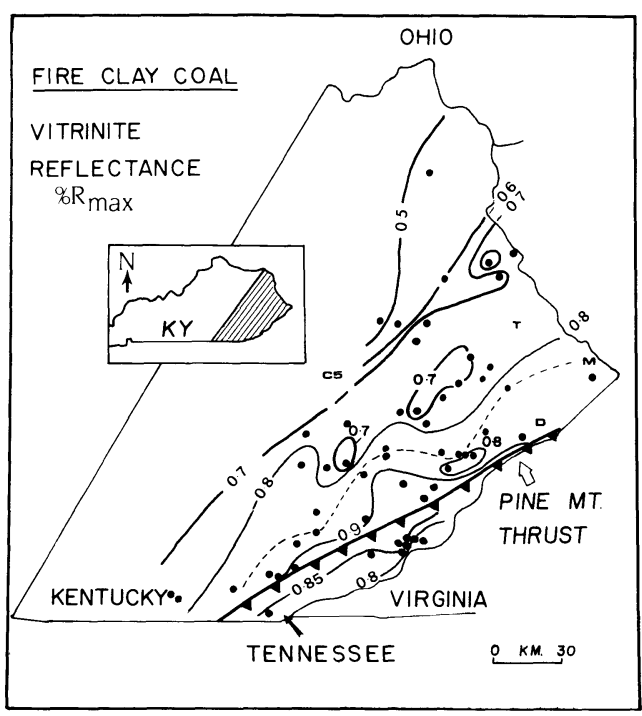

FIG. 1.-Contoured vitrinite maximum reflectance map for the Pennsylvanian Fire Clay coal in eastern Kentucky. Dashed line represents the $0.85 \%$ contour. Values increase from $0.5 \%$ in the north to approximately $1.0 \%$ to the southeast in front of the Pine Mountain thrust. South of the fault reflectance values decrease to $0.85 \%$ and $0.80 \%$. The concordance of contours within approximately $10 \mathrm{~km}$ of the trace of the fault and the lower reflectance values in the hanging wall at the same stratigraphic level suggest some maturation in the footwall was caused by the thrust (teeth on the upper plate). C5, D, M, and T indicate the location of bore holes, mine and outcrop samples used to estimate the regional reflectance gradient (fig. 2). Black arrow at the bottom of the figure indicates the location of the Cumberland pilot tunnel (fig. 4).

ments increases toward the orogen because of increasing depth of burial in that direction (Damberger 1974; Epstein et al. 1976). In addition, however, the Pine Mountain thrust may have contributed to the thermal maturation of these rocks in eastern Kentucky.

The Pine Mountain thrust, which crops out along strike for a distance of $200 \mathrm{~km}$ in eastern Kentucky and adjacent Virginia and Tennessee (fig. 1; Wentworth 1921; Rich 1934), overthrust coal-bearing Pennsylvanian sediments to the northwest in post-Pennsylvanian to Permian time (Harris and Milici 1977). The hangingwall, which rides on the Devonian Chattanooga Shale, is presently at least 1.0 km thick, and consists of Devonian to Pennsylvanian strata along its northwestern portion (Miller and Fuller 1954; Mitra 1988). The displacement on the thrust is about $20 \mathrm{~km}$ at the southwest end and about $3 \mathrm{~km}$ at the northeast end of the overthrust block (Wentworth 1921; Mitra 1988). An average displacement of $10 \mathrm{~km}$ is used in this paper.

\section{VITRINITE REFLECTANCE}

Measurements of maximum $\left(R_{\max }\right)$ and random mean $\left(R_{\text {mean }}\right)$ vitrinite reflectance were made on a single stratigraphic horizon, the mid-Pennsylvanian Fire Clay coal, which is dated at $310 \mathrm{Ma}\left({ }^{40} \mathrm{Ar} /{ }^{39} \mathrm{Ar}\right.$ sanidine age; D. Chestnut, Kentucky Geological Survey; pers, comm. 1988). Because the sanadine is part of a coal tonstein and is interpreted as a volcanic ash fall, its cooling age should correspond closely to its sedimentation age. This age is consistent with the stratigraphic position of the Fire Clay coal. The Fire Clay coal is mined and exposed over a large area in eastern Kentucky and on both sides of the Pine Mountain thrust. Measurements were also made on coals at different stratigraphic levels from drillholes, deep road cuts, and mine samples; this three-dimensional coverage allowed us to make estimates of reflectance gradients.

Each sample represents the average of 50 measurements determined on 20 mesh $(840$ $\mu \mathrm{m})$ particulate coal pellets. The standard deviation of vitrinite maximum reflectance for 3218 Kentucky coals, analyzed by the Kentucky Center for Applied Research, is $\mathbf{0 . 0 4 \%}$ $R_{\max }$. Regression of the data for this study indicate the following relationship between $\mathbf{R}_{\max }$ and $\mathbf{R}_{\text {mean }}$ :

$$
R_{\max }=1.04 R_{\text {mean }}
$$

All reflectance values reported here are $R_{\max }$. $R_{\text {mean }}$ values were used for purposes of reflectance-temperature conversions.

In general, the values of $R_{\max }$ increase progressively from $0.5 \%$ in the north to approximately $1.0 \%$ toward the southeast (fig. 1). South of the thrust, in the hangingwall, reflectance values decrease to $0.85 \%$ and $0.8 \%$ at the same stratigraphic level. Despite deeper burial, reflectance measurements on the underlying Devonian Ohio shale in the same region show very similar values as the Pennsylvanian coal. The values therefore appear to be suppressed (Rimmer and Cantrell 1989). Although there is considerable scatter in reflectance gradients, a representative 


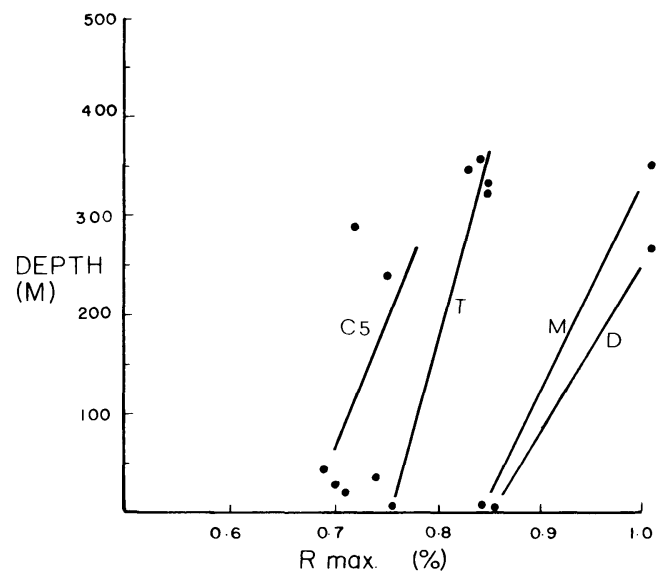

FIG. 2.-Plot of depth (meters) versus reflectance values $\left(R_{\max }, \%\right)$ for a borehole (C5) and mine and outcrop samples (T, M, D). Locations indicated on figure 1 . Slope of regression lines indicate regional gradient. A gradient of $0.3 R_{\max } / \mathrm{km}$ is taken as representative of the study area.

value for the region based on drillhole data as well as mine and outcrop samples is approximately $0.3 / \mathrm{km}$ (fig. 2 ).

\section{INTERPRETATION}

The increase in reflectance to the southeast can be attributed to the increased thickness of the Carboniferous sediments in this direction (e.g., Arkle 1974; Wanless 1975). In eastern Kentucky this general pattern is complicated, however, by several highs and lows in $R_{\max }$ (fig. 1). Although the origin of these anomalies is outside the scope of the present paper they appear to be related to basement structural offset and/or folds and faults within the overlying sediments (Hower and Rimmer 1990). It is notable that within approximately $10 \mathrm{~km}$ of the trace of the Pine Mountain thrust, these anomalies are diminished in magnitude and the isograds become subparallel to the trace of the fault. Evidently, reflectance values in this region record thermal overprinting by the thrust. Such an overprint would be consistent with the displacement on the thrust, which is on average approximately $10 \mathrm{~km}$ to the northwest. It is also consistent with the difference in grade across the fault from $1.0 \%$ in the footwall to $0.85 \%$ in the hangingwall at the same stratigraphic level. In general, in the southern Appalachians, in cases where thrusting post-dates thermal maturation, higher-grade rocks are observed in the hangingwall (Epstein et al. 1976; Harris and Milici 1977). Across the Pine Mountain thrust, however, the opposite pattern is observed. This is the pattern expected if maturation occurred during conductive thermal relaxation after thrusting (Oxburgh and Turcotte 1974; England and Thompson 1984; Fowler and Nisbet 1988). The reflectance data, however, apparently lack sufficient resolution to record the differential displacement across the thrust from the southwest to the northeast end. As a working hypothesis we attribute the maturation of the rocks to two dominant processes: pre-orogenic maturation up to $0.85 \%$ due to burial, followed by maturation to $1.0 \%$ due to the thermal effect of the overthrust.

Depth of Burial and Overthrust Thickness. - The amount of sediment removed by erosion in this region is poorly constrained because the upper Pennsylvanian Conemaugh, Monongahela, and Permian Dunkard Groups, and their stratigraphic equivalents (Arkle 1974), are not present in the area. Estimates can be made, however, from the reflectance values assuming a geothermal gradient based on reflectance gradients.

Considering that reflectance gradients of $0.15 \mathrm{R} \% / \mathrm{km}$ correspond to "normal" geothermal gradients $\left(\sim 30^{\circ} \mathrm{C} / \mathrm{km}\right.$; Robert 1988), reflectance gradients of $0.3 \mathrm{R} \% / \mathrm{km}$ observed in this study (fig. 2) suggest an elevated paleogeothermal gradient of approximately $60^{\circ} \mathrm{C} / \mathrm{km}$. This high gradient is not unreasonable in light of the inferred low conductivity of the shale-rich Pennsylvanian section (e.g., Blackwell and Steele 1988) and it is used here as the steady state gradient for rocks above and below the thrust.

Current interpretations of organic maturation can be represented by two end-member models. One model assumes that temperature plays the dominant role in organic maturation (Price 1983; Barker and Pawlewicz, 1986) whereas the other model considers time and temperature as important factors (e.g., Hood et al. 1975; Waples 1980). For example, in the former model, a reflectance value of $0.85 \%$, which is attributed to burial by sediment in the southeastern part of the study area, corresponds to a temperature of $128^{\circ} \mathrm{C}$ after converting to $R_{\text {mean }}$ (Barker and Pawlewicz, 1986). On the basis of time-dependent models the same reflectance value corresponds to 
temperatures of $115^{\circ}-130^{\circ} \mathrm{C}$ assuming an effective heating time of $30 \mathrm{Ma}$ (Hood et al. 1975; Waples 1980). This heating time is reasonable in light of the geologic constraints (deposition in Pennsylvanian time at $310 \mathrm{Ma}$ followed by thrusting in Permian time; Rodgers 1983). Using the above geothermal gradient these models give depths of burial between $1.9 \mathrm{~km}$ and $2.1 \mathrm{~km}$ and imply this amount of overburden was removed by erosion. Since the minimum present thickness of the overthrust block is approximately $1 \mathrm{~km}$ (Miller and Fuller 1954) and the Fire Clay coal on the overthrust displays reflectance values of $0.85 \%$ this constrains the Pine Mountain overthrust block to have been approximately $2.9-3.1 \mathrm{~km}$ thick prior to the onset of erosion.

\section{THERMAL EVOLUTION}

Thrust Emplacement.-A potentially important thermal effect during overthrusting is the production of a transient shallow or inverted thermal gradient immediately beneath the overthrust surface. This may be due to frictional heating effects and/or passive offset of isotherms (e.g., Scholz 1980). The possible role of frictional effects will be evaluated later on. Whether the isotherms are offset as a result of thrusting can be evaluated using the Peclet number (Oxburgh and Turcotte 1974), which is defined as the ratio of advective (i.e., tectonic) heat transport to conductive heat transport:

$$
P e=U L / k
$$

where $U$ is the thrust velocity, $L$ is the characteristic length, here taken as the overthrust thickness, and $k$ is the diffusivity $\left(k=K \rho C_{p}\right.$, where $K$ is the conductivity, $\rho$ is the density, and $C_{p}$ the specific heat capacity). In light of the likely shale/siltstone-rich nature of the Pennsylvanian section, indicating a low conductivity, a reasonable value for $k$ is $5 \times 10^{-3}$ $\mathrm{cm}^{2} / \mathrm{s}$. If $P e \gg 1$, the isotherms are offset as passive markers, but if $P e$ is close to 1 , then thermal relaxation will occur during thrust emplacement.

As pointed out by Karabinos (1988), it is the vertical rather than the horizontal velocity component of thrusting which will determine whether the isotherms are offset or not. In the case of the Pine Mountain thrust the vertical rate of offset of the isotherms $\left(V_{z}\right)$ is related to the angle of ramping $(\theta)$ and the horizontal velocity of thrusting $\left(V_{x}\right)$ by the following expression:

$$
V_{z}=V_{x} \tan \theta
$$

The angle of ramping along the thrust is approximately $20^{\circ}$ (Wiltschko 1979 ). The velocity of thrusting $\left(V_{x}\right)$ for Pine Mountain is poorly constrained but according to Elliott (1976) typical mean thrust velocities range between $10^{-7}$ and $10^{-8} \mathrm{~cm} / \mathrm{s}$. Using values of $L$ and $k$ above, Peclet numbers of between 0.2 and 2 are calculated. This result indicates that the isotherms would not be offset as passive markers unless the thrust velocity was substantially higher than the range suggested above. This result is in agreement with two dimensional thermal modeling of simple thrusts (Shi and Wang 1987) and indicates that a shallow and/or inverted thermal gradient would not normally be established. Provided erosion does not remove the thrust sheet prior to or during emplacement, however, heating of the lower plate will occur as the ambient geothermal gradient is reestablished, regardless of the velocity of thrust emplacement (England and Richardson 1977).

Uplift History.-Assuming for the present that the effects of erosion are negligible, the approximate time taken for the thrust surface to reach half the equilibrium temperature (the characteristic conductive relaxation time) is given by the expression $L^{2} / k$ (Carlslaw and Jaeger 1959, p. 60). Using the values above, the conductive relaxation time at the thrust surface is approximately $0.6 \mathrm{Ma}$. However, because the Fire Clay coal was buried between 1.9 and $2.1 \mathrm{~km}$ below the thrust surface, this time will be somewhat longer. At a depth of $2 \mathrm{~km}$ beneath the thrust the time calculated to reach half the equilibrium temperature $(t \rightarrow \infty)$ - using a modified solution to the heat flow equation (equation A-9 of Brewer 1981)-is $1 \mathrm{Ma}$. Therefore, the temperature at this depth would increase by approximately $90^{\circ} \mathrm{C}\left(300^{\circ}-120^{\circ} \mathrm{C}\right) / 2$; i.e., halfway to equilibrium) within this time period. Within this reflectance range this temperature corresponds to an increase in vitrinite reflectance of about 0.6 (Barker and Pawlewicz 1986). Using time dependant organic matura- 


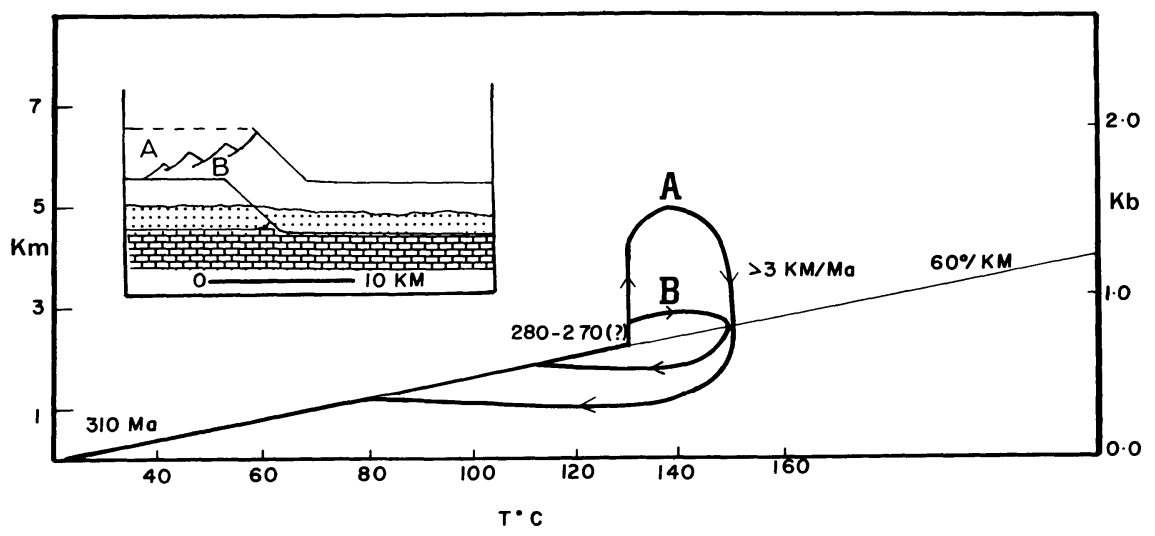

Fig. 3.-Two end member Pressure-Temperature-time paths (erosion and no erosion cases) for the Pennsylvanian Fire Clay coal in the vicinity of the Pine Mountain thrust. Geologic events common to both paths are formation of the Fire Clay coal at the surface at $310 \mathrm{Ma}$ (mid-Pennsylvanian), followed by burial to a depth of between 1.9 and $2.2 \mathrm{~km}$ for a period of 30-40 Ma, and then emplacement of the thrust in postPennsylvanian to lower Permian time (280-270 [?] Ma). Path A involves emplacement of a $3 \mathrm{~km}$ thick thrust without erosion resulting in burial of the Fire Clay coal to approximately $5 \mathrm{~km}$ in $1 \mathrm{Ma}$. Thermal equilibrium is not attained due to rapid uplift $(>3 \mathrm{~km} / \mathrm{Ma})$ immediately after thrust emplacement. Path $B$ involves erosion which results in emplacement of a thinner sheet which rapidly attains thermal equilibrium. Inset: Schematic cross-section across the Pine Mountain thrust showing thrusting without erosion (A) and with erosion (B). Brick pattern: Cambrian to Devonian succession; dotted pattern: Devonian to Pennsylvanian succession. Top of dotted pattern represents present erosion surface. The Fire Clay coal (not indicated) is close to this surface.

tion models (e.g., Waples 1980) for short periods of time (e.g., $1 \mathrm{Ma}$ ) even higher reflectance values are predicted, and longer heating times aggravate the problem. The observed increase in the Fire Clay coal in the lower plate is only $0.15 \%$, suggesting that equilibrium was not attained. It is concluded that uplift and erosion interupted heating within approximately $1 \mathrm{Ma}$ of emplacement of the thrust sheet. An alternative possibility is that erosion reduced the thrust thickness and hence the equilibrium temperature in the lower plate.

If uplift and erosion interupted heating in the lower plate after thrust emplacement, as outlined above, an uplift rate of greater than 3 $\mathrm{km} / \mathrm{Ma}$ is implied. Although erosion and uplift rates vary widely, this rate is typical of rapidly uplifting orogens (e.g., Dahlen and Suppe 1988). Applying this erosion rate at the time of initiation of thrusting implies a velocity of thrust emplacement greater than $10 \mathrm{~km} /$ $\mathrm{Ma}$, because at slower velocities a $3 \mathrm{~km}$ thick thrust sheet would be eroded before final emplacement. This, however, has not occurred, as indicated by the maturation levels in the upper plate (fig. 1).

On the other hand, the relatively long relaxation time for the thrust indicated above (1
Ma) suggests that substantial erosion of the thrust after it traveled over the ramp at Pine Mountain may have occurred prior to reaching thermal equilibrium. The duplicated section of the thrust, therefore, may have been substantially thinner than the $3 \mathrm{~km}$ maximum value suggested above. An increase of $0.15 \%$ $R_{\max }$ in the footwall relative to the hangingwall corresponds to a $20^{\circ} \mathrm{C}$ temperature difference (Barker and Pawlewicz 1986) and assuming it represents a close approximation to equilibrium it could be produced by a $0.33 \mathrm{~km}$ thick thrust sheet. Because the thermal relaxation time varies according to $\mathrm{L}^{2}$ such a thin sheet would reach thermal equilibrium rapidly in comparison to the time taken to further reduce its thickness by erosion.

In summary, the above considerations permit construction of two distinctly different P-T-t paths for the Pine Mountain thrust (fig. $3)$. The first path $(A$, fig. 3$)$ involves emplacement of a $3 \mathrm{~km}$ thick thrust sheet without substantial erosion and involves rapid ( $>3$ $\mathrm{km} / \mathrm{Ma}$ ) uplift and cooling within $1 \mathrm{Ma}$ of thrust emplacement. Thermal equilibrium is not attained in the footwall prior to uplift. The second path $(B$, fig. 3$)$ involves erosion during thrust motion such that a much thinner sheet is emplaced and thermal equilibrium is 
rapidly attained in the footwall. This situation can be expected where the rate of erosion approximately equals the vertical thrust velocity $\left(V_{z}\right.$ above; $\left.1-10 \mathrm{~km} / \mathrm{Ma}\right)$. Distinction between these scenarios might be possible on the basis of pressure estimates from fluid inclusions; a search for suitable inclusions, however, proved unsuccessful.

\section{DISCUSSION}

Role of Frictional Heating. - In contrast to deformation in the hinterland, considerable uncertainty exists as to whether thrust emplacement in the foreland of the southern Appalachians was controlled largely by frictional sliding (e.g., House and Gray 1982) or by ductile deformation (Wojtal and Mitra 1986). Evidence for ductile deformation in the form of foliated cataclastites has not been described from the Pine Mountain thrust, and tectonic solution features are only weakly developed (Wiltchko et al. 1985). Together with the brittle nature of faulting, these features suggest thrust emplacement occurred in the frictional regime. Some constraints can be placed on the mode of emplacement of the Pine Mountain thrust, particularly basal shear stress levels, by considering the role, if any, of frictional heating. Because of the sensitivity of organic matter to thermal effects, anomalous maturation levels of coal within and near faults provide good evidence for frictional heating (Bustin 1983).

Two cases of frictional heating can be important. The first case is the result of steadystate heating over the history of emplacement of the thrust and can result in a temperature increase of $100^{\circ} \mathrm{C}$ if average shear stresses of approximately $1 \mathrm{~kb}$ are maintained for $1 \mathrm{Ma}$ (Scholz 1980; Sibson 1983). Assuming frictional behavior under lithostatic conditions for a $3.0 \mathrm{~km}$ thick overthrust (path A, fig. 3) and a coefficient of friction of 0.85 (Brace and Kohlstedt 1980), a theoretical maximum basal shear stress of about 0.8 kbars for Pine Mountain is predicted. If this shear stress is maintained during emplacement of the thrust (for $1 \mathrm{Ma}$ at $1 \mathrm{~cm} / \mathrm{yr}$ ) a thermal anomaly can be expected (fig. $7 b$ of Sibson 1983). In the case of path B (fig. 3) the basal shear stress would be lower and any thermal anomaly would be correspondingly reduced. The second case of heating involves short-lived high velocity events, possibly seismic in nature,

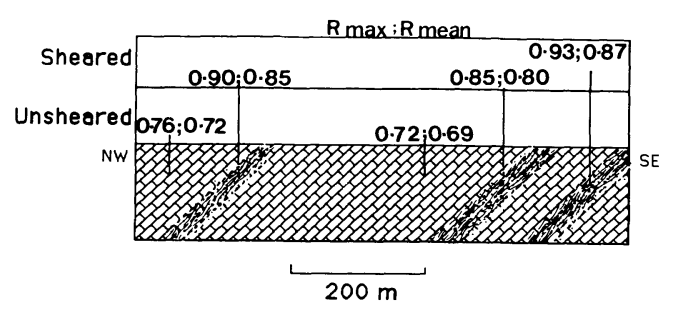

Frg. 4. - Schematic section through the Cumberland pilot tunnel (fig. 1, black arrow) showing maximum and mean reflectance values for sheared and non-sheared Pennsylvanian coals. Strata face to the northwest. Sheared coals display higher maximum and mean reflectance values compared to non-sheared samples regardless of their stratigraphic position. The role of frictional heating along faults is considered in the text.

resulting in localized and transient heating on the fault plane. For example, a temperature rise of approximately $100^{\circ} \mathrm{C}$ will be produced on a discrete fault surface which slips for 1 second at $1 \mathrm{~m} / \mathrm{s}$ against a shear resistance of 0.2 kbars (fig. 2 of Sibson 1980).

Vitrinite reflectance measurements on samples of Devonian shale from boreholes close to the detachment display values only gradationally higher than more distal samples, which is interpreted in terms of increasing depth of burial toward the fault (Rimmer and Cantrell 1989). On the other hand, Scholz (1980) pointed out that a decrease in metamorphic grade away from a fault on both sides is good evidence for frictional heating, and this pattern is observed in figure 1 . Because of the ambiguity, however, in separating pre-orogenic heating due to burial from frictional heating, it is difficult to confirm the occurrance of a regional frictional heating event. Moreover, the steady-state thermal anomaly predicted above assumes a constant heat flux (Carslaw an Jaeger 1959, p. 75) which in the present context implies slip occurred over the entire thrust surface simultaneously. The differential slip along the Pine Mountain thrust, together with the complex deformation in the hangingwall (Harris and Milici 1977), makes this unlikely.

The possibility of frictional heating on a local scale is supported by samples from the Cumberland pilot tunnel in the upper plate of the thrust (fig. 1). Sheared and slickensided samples of Pennsylvanian coal from fault zones in the tunnel display higher $R_{\max }$ values compared to unsheared samples (fig. 4 ). $R_{\text {mean }}$ 
values also show the same pattern. The absence of chemical alteration of coals along the faults suggest that higher values in sheared samples may be due to frictional heating rather than hydrothermal fluid circulation along fault planes. Assuming the faults deformed approximately by simple shear, the reflectance fabric might be expected to show an increase in $R_{\max }$, a decrease in $R_{\min }$ and no change in $R_{\text {intermediate }}$ (Levine and Davis 1983). Although detailed three-dimensional reflectance analysis has not been attempted in this study, the observation that $\mathbf{R}_{\text {mean }}$ as well as $\mathbf{R}_{\max }$ display higher values along the faults suggests that differential stress is not the sole cause of the increased reflectance and that frictional heat played a role.

Assuming the heating effect is confined to within centimeters or less of the fault surface the approximate maximum duration of the heating can be estimated from $t=L^{2} / k$, which yields a value of approximately $1000 \mathrm{~s}$. Such short-lived thermal pulses would preclude the development of equilibrium reflectance values (Bostick and Pawlewicz 1984). The observed increase in reflectance of approximately $0.15 \%$ between sheared and unsheared samples represents an absolute minimum estimate for the actual temperature rise. Substantial rises in temperature $\left(>100^{\circ} \mathrm{C}\right)$ can be produced along faults with shear stresses as low as $0.1 \mathrm{kbars}$ provided the velocity and duration of slip are sufficient (equation 18, Sibson 1983).

Calcite twin patterns at one locality for the Pine Mountain thrust are interpreted to indicate that shear stresses may have been as low as $0.1 \mathrm{~kb}$ (Wiltschko et al. 1985). Frictional sliding on the Chattanooga Shale, however, which is composed largely of illite and chlorite (Hosterman and Whitlow 1983), would likely require higher shear stress unless sliding occurred under conditions of elevated fluid pressure (low effective stress) or involved other clays with substantial amounts of interlayer water (Shimamoto and Logan 1981). The modal increase of illite and the decrease in smectite-illite mixed layer clays with depth in Devonian shales in the Appalachian basin (Hosterman and Whitlow 1983) suggests a mechanism to generate elevated fluid pressure on the Devonian detachment. The increased ordering of phyllosilicates, either due to strain-induced recrystallization (Lee et al. 1986), or increase in temperature (frictional or otherwise) could result in production of water and elevated fluid pressure along segments of the detachment.

\section{CONCLUSIONS}

1) Maximum vitrinite reflectance values and regional reflectance gradients in front of the Pine Mountain thrust in eastern Kentucky indicate a pre-orogenic depth of burial of approximately $2.0 \mathrm{~km}$, implying an original thickness of approximately $3 \mathrm{~km}$ for the thrust sheet prior to erosion.

2) The concordance of isograds with the trace of the thrust and the lower reflectance values in the hanging wall suggest thrusting enhanced thermal maturation of coals in the footwall. The reflectance values are consistent with emplacement without erosion of a 3 $\mathrm{km}$ thrust sheet followed by rapid uplift $(>3$ $\mathrm{km} / \mathrm{Ma}$ ) and cooling within $1 \mathrm{Ma}$. The data are also consistent with a situation whereby erosion kept pace with thrust motion resulting in emplacement of a substantially thinner sheet which rapidly attained thermal equilibrium.

3) The apparent absence of a regional frictional heating effect along the thrust is consistent with a weak detachment, possibly due to elevated fluid pressure caused by evolution of water during dehydration of clays.

Acknowledgments. - Work at the Center for Applied Energy Research supported by grants from the Kentucky Energy cabinet, Commonwealth of Kentucky. Journal reviews by Michael Underwood and an anonymous reviewer substantially improved the manuscript. Discussions early on with Bill Blackburn and N. Rast are gratefully acknowledged.

\section{REFERENCES CITED}

ArkLe, T., Jr., 1974, Stratigraphy of the Pennsylvanian and Permian systems of the Central Appalachians in BrIGgs, G., ed., Carboniferous of the southeastern United States: Geol. Soc. America Spec. Paper 148, p. 5-29.

Barker, C. E., and Pawlewicz, M. J., 1986, The 
correlation of vitrinite reflectance with maximum temperature in humic organic matter, in BHATTACHARJI, S.; et al., eds., Lecture Notes in Earth Science, 5. Paleogeothermics: New York, Springer-Verlag, p. 79-93.

Blackwell, D. D., and Steele, J. L., 1988, Thermal conductivity of sedimentary rocks: measurements and significance, in NAESER, N. D., and McCulloh, T. H., eds., Thermal history of sedimentary basins, New York, SpringerVerlag, p. 13-36.

Bostick, N. H., and Pawlewicz, M. J., 1984, Paleotemperatures based on vitrinite reflectance of shales and limestones in igneous dike aureoles in the upper Cretaceous Pierre shale, Walsenburg, Colorado, in Woodward, J; MeIssner, F. F.; and Clayton, J. L., eds., Hydrocarbon source rocks of the greater Rocky Mountain region: Rocky Mountain Assoc. Geol., p. 387-392.

Brace, W. F., and Kohlstedt, D. L., 1980, Limits on lithospheric stress imposed by laboratory experiments: Jour. Geophys. Res., v. 85, p. 62486252.

BREWER, J., 1981, Thermal effects of thrust faulting: Earth Planet. Sci. Lett., v. 56, p. 233-244.

Bustin, R. M., 1983, Heating during thrust faulting in the Rocky Mountains: friction or fiction?: Tectonophysics, v. 95, p. 309-328.

Carslaw, H. S., and Jaeger, J. C., 1959, Conduction of Heat in Solids ( $2 \mathrm{~d}$ ed.), Oxford, Oxford Univ. Press, $510 \mathrm{p}$.

Crawford, M. L., and Mark, L. E., 1982, Evidence from metamorphic rocks for overthrusting, Pennsylvania Piedmont, USA: Can. Mineral., v. 20, p. 333-347.

DAHLEN, F. A., and SuPPE, J., 1988, Mechanics, growth, and erosion of mountain belts, in CLARK, S. P., JR.; BurChFIEL, C. B.; and SuPPE, J., eds., Processes in continental lithospheric deformation: Geol. Soc. America Spec. Paper 218, p. 161-178.

Damberger, H. H., 1974, Coalification patterns of Pennsylvanian coal basins of the eastern United States, in Dutcher, R. R.; et al., eds., Carboniferous material as indicators of metamorphism: Geol. Soc. America Spec. Paper 153, p. 53-74.

Elliott, D., 1976, The energy balance and deformation mechanisms of thrust sheets: Proc. Royal Soc. (London), Ser. A, v. 283, p. 289-312.

England, P. C., and Richardson, S. W., 1977, The influence of erosion upon the mineral facies of rocks from different metamorphic environments: Jour. Geol. Soc. (London), v. 134, p. 201-213.

- and Thompson, A. B., 1984, Pressuretemperature-time paths of regional metamorphism. I, heat transfer during evolution of regions of thickened crust: Jour. Petrol., v. 25, p. 894-928.

England, T. D. J., and Bustin, R. M., 1986, Effect of thrust faulting on organic maturation in the southeastern Canadian cordillera: Organic Geochem., v. 10, p. 609-616.

Epstein, A. G.; Epstein, J. B.; and Harris, L. D., 1976, Conodont color alteration-an index to organic metamorphism: U.S. Geol. Survey Prof. Paper 995, 27 p.
Fowler, C. M. R., and Nisbet, E. G., 1988, Geotherms in the continental crust and metamorphism, in Nisbet, E. G., and Fowler, C. M. R., eds., Short course on heat, metamorphism, and tectonics, St. Johns, May, 1988: Mineral. Soc. Canada, v. 14 , p. 34-50.

Harris, L. D., and Milici, R., 1977, Characteristics of thin-skinned style of deformation in the southern Appalachians and potential hydrocarbon traps: U.S. Geol. Survey Prof. Paper 1018, $40 \mathrm{p}$.

Hood, A.; Gutuahr, C. C. M.; and Heacock, R. L., 1975, Organic metamorphism and the generation of petroleum: AAPG Bull., v. 59., p. 986-996.

Hosterman, J. W., and Whitlow, S. I., 1983, Clay mineralogy of Devonian shales in the Appalachian basin: U.S. Geol. Survey Prof. Paper 1298, $31 \mathrm{p}$.

House, W. M., and Gray, D. R., 1982, Cataclastites along the Saltville thrust, USA and their implications for thrust emplacement: Jour. Struct. Geol., v. 4, p. 257-269.

Hower, J. C., and Rimmer, S. M., 1990, Coal rank trends in the central Appalachian coalfield: Virginia, West Virginia, and Kentucky: Organic Geochem., in press.

Karabinos, P., 1988, Heat transfer and fault geometry in the Taconian thrust belt, western New England, in Mitra, G., and Wojtal, S., eds., Geometries and mechanisms of thrusts: Geol. Soc. America Spec. Paper 222, p. 35-45.

Lee, J. H.; Peacor, D. R.; Lewis, D. D.; and WINTSCH, R. P., 1986, Evidence for syntectonic crystallization for the mudstone to slate transition at Lehigh Gap, Pennsylvania, USA: Jour. Struct. Geol., v. 8, p. 767-780.

Levine, J. R., and Davis, A., 1983, Tectonic history of coal-bearing sediments in eastern Pennsylvania using coal reflectance anistropy: Pennsylvania St. University, Spec. Res. Rept. SR$118,314 \mathrm{p}$.

Miller, R. L., and Fuller, J. O. 1954, Geology and oil resources of the Rose Hill district-the fenster area of the Cumberland overthrust block-Lee county, Virginia: Virginia Geol. Survey Bull., v. 71, 383 p.

Mitra, S., 1988, Three-dimensional geometry and kinematic evolution of the Pine Mountain thrust system, southern Appalachians: Geol. Soc. America Bull., v. 100, p. 72-95.

OxBurgh, E. R., and TurcotTe, D. L., 1974, Thermal gradients and regional metamorphism in overthrust terrains with special reference to the eastern Alps: Schwitzer Minerologie und Petrologie Mitteilung., v. 54, p. 641-662.

Price, L. C., 1983, Geologic time as a parameter in organic metamorphism and vitrinite reflectance as a absolute paleogeothermometer: Jour. Petrol. Geol., v. 6, p. 5-38.

Rich, J. L., 1934, Mechanisms of low-angle overthrust faulting as illustrated by Cumberland thrust block, Virginia, Kentucky, and Tennessee: AAPG Bull., v. 18, p. 1584-1596.

Rimmer, S. M., and Cantrell, D. J., 1989, Organic maturation of the Cleveland member of the Ohio shale, eastern Kentucky, in Proc. Eastern Oil 
Shale Symposium (Lexington, Kentucky) 1988: Inst. Mining Minerals Res., p. 401-410.

RoBert, P., 1988, Organic metamorphism and Geothermal History: Sedimentology and Petroleum geology: Dordrecht Reidel, $311 \mathrm{p}$.

RODGERs, J., 1983, The life history of a mountain range-the Appalachians, in Hsü, K., ed., Mountain Building Processes: London, Academic Press, p. 229-241.

Scholz, C. H., 1980, Shear heating and the state of stress on faults: Jour. Geophys. Res., v. 85, p. 6174-6184.

SHI, Y., and WANG, C.-Y., 1987, Two-dimensional modeling of the P-T-t paths of regional metamorphism in simple overthrust terrains: Geology, v. 15, p. 1048-1051.

Shimamoto, T., and Logan, J. M., 1981, Effects of simulated clay gouges on the sliding behavior of Tennessee sandstone: Tectonophysics, v. 75., p. 243-255.

Sibson, R. H., 1980, Power dissipation and stress levels on faults in the upper crust: Jour. Geophys. Res., v. 85, p. 6239-6247.

1983, Continental fault structure and the shallow earthquake source: Jour. Geol. Soc. (London), v. 140, p. 741-767.

TANKARD, A. J., 1986, Depositional response to foreland deformation in the Carboniferous of eastern Kentucky: AAPG Bull., v. 7, p. 853-868.
UnderwOOD, M. B.; Fulton, D. A.; and McDonald, K. W., 1988, Thrust control on the thermal maturity of the frontal Ouachita mountains, Central Arkansas, USA: Jour. Petrol. Geol., v. 11, p. 325-340.

WANLESS, H. R., 1975, Paleotectonic investigations of the Pennsylvanian System in the United States: U.S. Geol. Survey Prof. Paper 853-C, p. 16-62.

WAPLES, D. W., 1980, Time and temperature in petroleum formation: application of Lopatin's method to petroleum exploration: AAPG Bull. v. 64., p. 916-926.

Wentworth, C. K., 1921, Russell Fork fault of southwest Virginia: Jour. Geology, v. 29, p. 351369.

Wiltschко, D. V., 1979, A mechanical model for thrust sheet deformation at a ramp: Jour. Geophys. Res., v. 84, p. 1091-1104.

; MedwedefF, D. A.; and Millson, H. E., 1985, Distribution and mechanisms of strain within rocks on the northwest ramp of Pine Mountain block, southern Appalachians foreland: a field test of theory: Geol. Soc. America Bull., v. 96, p. 426-435.

Wojtal, S. and Mitra, G., 1986, Strain hardening and strain softening in fault zones from foreland thrusts: Geol. Soc. America Bull., v. 97, p. 674687. 